\title{
16. Juliana v. United States and the global youth-led legal campaign for a safe climate
}

\author{
Patti Moore, Danny Noonan and Erik \\ Woodward
}

I have no doubt that the right to a climate system capable of sustaining human life is fundamental to a free and ordered society. (U.S. District Court Judge Ann Aiken, Juliana v. United States, 217 F. Supp. 3d 1224, 1250 (D. Or., 2016))

\section{INTRODUCTION}

The year 2018 heralded two pivotal moments in the climate crisis. On August 20, Greta Thunberg held the first of her school strikes that would quickly ignite a global movement. Less than two months later, on October 8, the Intergovernmental Panel on Climate Change (IPCC) released its Special Report on global warming of $1.5^{\circ} \mathrm{C}$ above pre-industrial levels, giving rise to the "12 years" (now ten) narrative and crystallizing the scale and urgency of the climate crisis for the general public.

There was almost a third moment. On October 29, the constitutional climate change lawsuit Juliana v. United States, filed in the U.S. federal courts in 2015 by 21 young Americans against the executive branch of the U.S. government, was supposed to begin trial. But ten days prior to trial, the U.S. Supreme Court intervened and issued a temporary stay, leading to a delay and appellate process that is ongoing at the time of print. ${ }^{1}$ More importantly, preventing trial has prevented the U.S. government's culpability for the climate crisis from being scrutinized in a court of law.

While the Juliana plaintiffs await their day in court, the movement their lawsuit anticipated continues to grow. New lawsuits inspired by the Juliana case continue to be filed in the United States and globally, ${ }^{2}$ and youth are taking to the streets in ever-increasing numbers to protect their right to a livable climate. ${ }^{3}$ This chapter provides an overview of the legal and factual bases for the Juliana lawsuit, and its connections to other lawsuits and the burgeoning youth-led response to the climate crisis. 


\section{JULIANA V. UNITED STATES}

On August 12, 2015, 21 youth plaintiffs filed a suit against the United States and several of its agencies. Also named as plaintiffs are future generations, with climate scientist James Hansen as guardian, and the non-profit organization Earth Guardians. The suit alleges that the U.S. government has known since the 1960s that fossil fuels are causing global warming, and that unless emissions are drastically reduced, the consequences will be catastrophic. Despite this knowledge, the government has continued to subsidize, promote, and authorize consumption of fossil fuels. The litany of dangers this has created to the natural systems on which its citizens depend is immense and has resulted in specific, present-day injuries to each of the individual Juliana plaintiffs.

The legal claims in Juliana can be said to fall into four broad categories.

First, the fact that climate change is substantially caused by the actions of the U.S. government, and is presently causing harms to the youth plaintiffs' recognized constitutional rights to life, liberty, property, personal security, bodily integrity, and family autonomy, means that the actions of the U.S. government should be subject to "strict scrutiny" by the courts. The Juliana plaintiffs further argue that a climate system capable of sustaining human life underpins each of the previously recognized constitutional rights, and therefore itself should be recognized as a constitutional right. ${ }^{4}$

Second, the Juliana plaintiffs allege that the U.S. government has assumed control over fossil fuel regulation, the atmosphere, and the climate system, taking the ability to meaningfully affect these systems out of the hands of its citizens and contributing to dangerous levels of greenhouse gases in the climate. Because it has assumed this responsibility, and because its actions render its citizens more vulnerable to dangerous climate change, it has a constitutional duty to act to minimize those dangers. It has repeatedly and systematically failed to do, despite knowing the likely effects of its actions to continue to support systems that will harm its citizens.

Third, because the harms of climate change fall disproportionately upon young people and future generations, the lives and quality of life of these citizens are being subordinated for the advantage of past and present adults. Thus, children as a group are being discriminated against with respect to their fundamental rights and are therefore not receiving equal protection under the law as guaranteed in the U.S. Constitution. And fourth, the Juliana plaintiffs argue that the "public trust doctrine" - an ancient legal doctrine that can be traced through the common law to Roman law - requires the U.S. government to prevent substantial impairment to the atmosphere and other commonly held 
natural resources that depend on a healthy atmosphere, including coastlines and territorial waters.

The Juliana plaintiffs do not seek monetary compensation; instead, they request a national remedial plan to phase out fossil fuel emissions and draw down excess atmospheric carbon. The good news is that this remedy is achievable with the coordinated efforts of multiple government agencies mobilizing different sectors of society. Government is the only force that can compel that level of effort in the remaining, rapidly narrowing window of opportunity to avoid surpassing climatic tipping points. Because the political branches have failed to do so, instead doubling down on fossil fuels, the Juliana plaintiffs seek an injunction from the courts that will order the legislative and executive branches of the government to cease the actions that have brought our climate to the brink of disaster, and to implement a plan commensurate with returning atmospheric concentrations of greenhouse gases to safe levels.

\section{THE SCIENCE SUPPORTING JULIANA}

Much of the media coverage around the IPCC's $1.5^{\circ} \mathrm{C}$ Special Report focused on the 12-year window in which global temperatures can be kept below the $1.5^{\circ} \mathrm{C}$ threshold, along with the apocalyptic consequences of warming beyond that threshold. Largely overlooked in this coverage was the report's statement that "Warming of $1.5^{\circ} \mathrm{C}$ is not considered 'safe' for most nations, communities, ecosystems and sectors and poses significant risks to natural and human systems as compared to the current warming of $1^{\circ} \mathrm{C}$ (high confidence)." ${ }^{\prime}$ Therefore, $1.5^{\circ} \mathrm{C}$ of global warming is no safe haven for humanity, or for human rights. Greater ambition is needed than even that implied by the " 12 years" narrative.

These latter findings were no surprise to the plaintiffs, lawyers, and expert witnesses behind Juliana v. United States. Over 20 experts support Juliana and have helped to develop the evidence and scientific arguments that link the government's actions to present and imminent harms. These experts are in consensus that the politically motivated Paris Agreement targets, $1.5^{\circ} \mathrm{C}$ and "well below" $2^{\circ} \mathrm{C}$, are dangerously high, and that returning atmospheric $\mathrm{CO}_{2}$ concentrations to under $350 \mathrm{ppm}$ - consistent with returning global temperatures to $1{ }^{\circ} \mathrm{C}$ above pre-industrial levels by 2100 - is necessary to preserve a safe climate.

\section{THE FIERCE URGENCY OF NOW MEETS THE LONG ARC TOWARDS JUSTICE}

Clearly the stakes in Juliana are high. Major impacts are already being felt by the Juliana plaintiffs, communities through the U.S. and around the world, 
including drought, massive storms, forest fires, crop failures, and deadly heatwaves. And time is running out to mitigate these impacts and prevent catastrophe. For children, the dissonance between this sense of urgency and the Trump administration's seemingly headlong rush towards disaster, fueled by its full-throated support of fossil fuels, is especially alarming.

Compounding this frustration is the fact that, although the Juliana plaintiffs filed their claim in 2015, and although the plaintiffs had fought off a myriad of government challenges, the case did not reach trial. Instead, over the past four years, the government defendants have filed a nearly unprecedented onslaught of dilatory motions and petitions. ${ }^{6}$ The case has gone before the Ninth Circuit five times and the Supreme Court twice. Following the temporary stay issued by the Supreme Court in October 2018 and a subsequent temporary stay issued by the Ninth Circuit in December 2018, the district court certified an interlocutory appeal of its earlier decisions, placing the immediate fate of the case in the hands of the appellate courts. On June 4, 2019, a three-judge panel of the Ninth Circuit Court of Appeals heard oral arguments for this appeal. On January 17, 2020, the Court ruled to dismiss the case in a two-to-one decision, finding that it was beyond the power of the courts to "order, design, supervise, or implement the plaintiffs' requested remedial plan." The dissenting judgment was scathing of this reasoning, stating:

My colleagues throw up their hands, concluding that this case presents nothing fit for the Judiciary... But a federal court need not manage all of the delicate foreign relations and regulatory minutiae implicated by climate change to offer real relief, and the mere fact that this suit cannot alone halt climate change does not mean that it presents no claim suitable for judicial resolution. ${ }^{8}$

The plaintiffs have now filed an "en banc" petition, seeking further review from the Ninth Circuit. ${ }^{9}$ Should the plaintiffs not succeed there, their final recourse is the Supreme Court.

The unprecedented extent to which the current administration has gone to obstruct litigation and delay judicial accountability attests to both the lawsuit's enormous stakes, and the threat it poses to existing structures of political and economic power. These extraordinary delay tactics are but a further example of the U.S. government's long-term abdication, in the name of short-term political expediency, of its duties to ensure the survival of its citizenry. The gravity of the youths' allegations compels that they have their day in court. If they succeed, the government will finally have to undo the damage it has been knowingly causing to the climate system for over 50 years. 


\section{GLOBAL YOUTH IN THE COURTS AND IN THE STREETS}

The odds are so stacked against the Juliana plaintiffs, as well as other young people fighting for a stable climate, that they could be forgiven for crumbling under the weight of it all. But today's youth have a different idea. In the words of Juliana plaintiff Vic Barrett, "We are learning every day that we are the ones who must secure our future. We must do the work. We must take to the streets. Being young is being an activist today." 10

Juliana not only presaged the global youth-led climate movement, it continues to be a major part of it. Particularly in recent years, young people have formed the vanguard of a movement demanding that governments take decisive, science-based action to mitigate both the causes and impacts of climate change and to ensure that a hospitable climate system can be enjoyed by future generations. That movement is growing - on March 15, 2019, an estimated 1 million people in 125 countries and spanning all seven continents participated in the Global Climate Strike for the Future ${ }^{11}$ - and it's working, having been recognized by the Secretary General of the Organization of Petroleum Exporting Countries as the "greatest threat" to the survival of the fossil fuel industry. $^{12}$

Where activism alone has been unable to yield the urgent action demanded by climate change, youth across the globe have drawn inspiration from the Juliana plaintiffs and taken their governments to court. Youth plaintiffs have initiated litigation against their governments in at least ten countries to compel science-based government action on climate change. ${ }^{13}$ These young plaintiffs have already set groundbreaking legal precedent and advanced critical legal victories. For example, in 2018 the Supreme Court of Colombia held that the constitution protects the right to a healthy environment and climate, and ordered the Colombian government to prepare a plan to prevent deforestation in the Colombian Amazon. ${ }^{14}$ Similar youth-led lawsuits to the Juliana case are in progress in Canada, Pakistan, Uganda and India, and several more are in the works.

\section{CONCLUSION}

In the fight for climate stability, the stakes could not be higher nor the timeline more urgent. When the political branches of government fail to act, the courts can intervene to compel that action. It is the most basic duty of any government to ensure that its people have the opportunity to live productive, dignified lives. The science is clear that the fundamental right to a safe climate is not a right that can be left to future generations to realize; it must be secured now 
or not at all. Never before has it been so imperative that the courts hear the evidence and enjoin the governments of the world to take the action they have so far refused to take.

While others are suing the courts, public support for their efforts and for the activism occurring around the world is essential. Only when the voices and votes of the public speak louder than the money of fossil fuel interests will meaningful change happen. And the time for meaningful change was yesterday. While youth advocate in the courts for the protections we deserve, we also must be advocating in the streets, in the voting booths, in the media and wherever we have a chance. Too much is at stake.

\section{NOTES}

1. John Schwartz, "Judges give both sides a grilling in youth climate case against the government," New York Times (June 4, 2019), accessed March 22, 2020 at http:// www.nytimes.com/2019/06/04/climate/climate-lawsuit-juliana.htm.

2. Sabin Center for Climate Change Law (2020), "Climate Change Litigation Databases," accessed March 22, 2020 at http://www.climatecasechart.com.

3. Alejandra Borunda, "These young activists are striking to save their planet from climate change," National Geographic (March 13, 2019), accessed March 22, 2020 at http://www.nationalgeographic.com/environment/2019/03/youth-climate -strike-kids-save-the-world/.

4. Juliana v. United States, 217 F. Supp. 3d 1224, 1249-50 (D. Or. 2016).

5. Roy, Joyashree, Petra Tschakert and Henri Waisman et al. "Sustainable development, poverty eradication and reducing inequalities." In Intergovernmental Panel on Climate Change (IPCC), Global Warming of $1.5^{\circ} \mathrm{C}$. An IPCC Special Report on the impacts of global warming of $1.5^{\circ} \mathrm{C}$ above pre-industrial levels and related global greenhouse gas emission pathways, in the context of strengthening the global response to the threat of climate change, sustainable development, and efforts to eradicate poverty (2018, p. 455).

6. Stephen Vladeck, "Comment: the Solicitor General and the shadow docket," 133 Harvard Law Review 123 (2019), 144-6.

7. Juliana v. United States, No. 178-36082, 2020 WL 254149 (9th Cir. January 17, 2020), App. 25.

8. Ibid., p. 33.

9. An en banc (lit. in bench) review is a session in which a case is heard before all the judges of a court rather than by one judge or a panel of judges. It is often used for unusually complex cases. See Jonathan Adler, "Kids climate plaintiffs to seek rehearing en banc," Reason (January 20, 2020), accessed March 22, 2020 at https://reason.com/2020/01/20/kids-climate-plaintiffs-to-seek-rehearing-en-banc.

10. No Ordinary Lawsuit: Mini Episode: The Plaintiffs Rally in Portland (July 22, 2019) [podcast], accessed March 22, 2020 at https://www.podbean.com/ew/dir -b2x7m-687e6d5.

11. Jessica Glenza, Alan Evans, Hannah Ellis-Petersen and Naaman Zhou, "Climate strikes held around the world - as it happened," The Guardian (March 15, 2019), accessed March 22, 2020 at http://www.theguardian.com/environment/live/2019/ mar/15/climate-strikes-2019-live-latest-climate-change-global-warming. 
12. Greta Thunberg, "Greta Thunberg: 'They see us as a threat because we're having an impact'," The Guardian (July 21, 2019), accessed March 22, 2020 at https:// www.theguardian.com/culture/2019/jul/21/great-thunberg-you-ask-the-questions -see-us-as-a-threat.

13. Globally, youth-led climate lawsuits have been brought in the United States, Canada, India, Korea, Mexico, Pakistan, Peru, Uganda, the Ukraine, Sweden, Norway, Colombia, Canada and New Zealand. In the United States alone, at least four separate lawsuits are currently pending at the state (i.e., subnational) level.

14. DeJusticia, "Climate change and future generations lawsuit in Colombia: key excerpts from the Supreme Court's decision" (April 13, 2018), accessed March 22, 2020 at https://www.dejusticia.org/en/climate-change-and-future-generations -lawsuit-in-colombia-key-excerpts-from-the-supreme-courts-decision/. 